\title{
Level of Knowledge Regarding Food Hygiene Among food Handlers Working in Restaurants of Doiwala, Dehradun
}

\author{
Madhup ${ }^{1}$, Sakshi $^{1}$, Saurabh $^{1}$, Shalini $\mathrm{Y}^{1}$,Sharon ${ }^{1}$,Sheetal,Shefalir ${ }^{1}$, Shilpi ${ }^{1}$,Shweta \\ $\mathrm{N}^{1}$ Sarla $^{1}, \mathrm{Ms}$. Anjana Williams ${ }^{2} \mathrm{mrs}$. Shiwani Verma ${ }^{3}$ \\ Students Of Bachler's Of Nursing ${ }^{l}$, Himalayan College Of Nursing \\ Senior Nursing Tutor ${ }^{2}$, Mental Health Nursing, Himalayan College Of Nursing \\ Clinical Instructor ${ }^{3}$, Medical Surgical Nursing, Himalayan College Of Nursing
}

\begin{abstract}
Food borne diseases are well recognized health problems in health care, they are caused by bacteria, virus, parasites or chemical contamination of food. ${ }^{3}$ The hands of an individual can be the vector to spread harmful micro-organism through cross contamination. A Quantitative Nonexperimental cross sectional exploratory design was used to assess the food handler's knowledge. Out of 23 restaurants 15 were selected through simple randomization techniques and with total enumerative sampling 77 food handlers were selected who met the inclusion criteria for the study. The data was collected with the help of demographic profile and structured knowledge questionnaire. The study finding revealed that $90 \%$ participants were between the age group of 18-36 years. Working experience of the $84 \%$ participants were 0-10 years. Statistical significant association was found between level of knowledge score and qualification (7.59)
\end{abstract}

Keywords: Knowledge, Food hygiene, Food handlers

\section{Introduction}

Any consumable substance which provides nutritional support for the body is called food. It usually comes from a plant or animals and contains essential nutrients needed for human body. Food produces energy to keep an individual warm,healthy and to work.It also protects against infections, also to recover from sickness. Although contaminated food can cause serious health problems, therefore it is necessary to maintain good food hygiene. Food hygiene is one of the important measures to ensure the safety. Food bornediseases are well recognized health problems in health care; they are caused by bacteria,virus,parasites or chemical contamination of food. Diarrhoea is the most common symptoms of food poisoning, which can be the consequences of food contamination, lack of food safety measures and less periodic evaluation. Food handlers play an important role in ensuring food safety. Thepeople who come in direct contact with food for food production,processing, packaging and distribution (including raw milk for direct consumption) have relatively increased number of food borne disease outbreaks.

The incidence of food borne outbreaks caused by contaminated fresh fruit and vegetables has increased in recent years. In India, food-borne diseases and infections causes' serious health hazard in large numbers and high incidence of morbidity and mortality rates. ${ }^{5}$ The risk of food contamination depends largely upon the health status of the food handlers, their personal hygiene, knowledge and practice of food hygiene (Mead PS, 1999). Infections can also be acquired through contaminated unwashed fingers, insects, and circulation of bank notes and by wind during dry conditions. Food can be contaminated at any point during harvesting, storage, distribution, transportation and preparation. Improper food hygiene practices can lead to food borne diseases. This crucial matter is neglected sometime. Each year 9.4 million people suffer from food borne diseases throughout the world; everyday cases related to food borne diseases are recorded in all over countries from the most to the least developed ones. Also in various industrialized countries, the statistics shows that about $60 \%$ of foods borne illnesses are caused by poor food handling techniques and during food serving. ${ }^{6}$ The United States of America reports around 76 million food borne diseasesoccurs annually with hospitalization of 325,000 people and 5200 cases of death. ${ }^{4}$

Approximately10 to $20 \%$ of food-borne disease outbreaks are due to contamination by the food handler. The mishandling of food, disregard of hygienic measures enable pathogens to come into contact with food and, in some cases, to survive and multiply in sufficient numbers to cause illness in consumers. Personal hygiene and environmental sanitation are key factors in the transmission of food borne diseases. About 10-30\% of healthy person carry bacteria in nose and skin,axilla,perineum and throat. ${ }^{3}$ The knowledge and practice of food handlers on food safety plays an important role. The proper training of the food handlers helps to prevent food borne illnesses to great extent. But the training provided for the food handlers are very less and the reviews shown that even though many restaurants are emerging day by day, the training for proper practice of safe 
handling of food is inadequate. The purpose of the study was to assess the level of knowledge regarding food hygiene among food handlers, working restaurants of Jolly grant.

\section{Research Methodology}

The research approach chosen for the study was quantitative research approachwithcross sectional exploratory design. Total 77 food handlers were selected thorough total enumeration sampling technique. The food corners, restaurant and dhaabas were selected through simple random sampling technique. The study excluded food handlers who were physically and mentally unfit. Demographic profile was used to collect the demographic variables and self- developed Knowledge questionnaire was used to collect the data.

\section{Analysis And Interpretation}

Section A: Frequency and percentage of demographic data

Table No.1:-Frequency and Percentage distribution of study participants.

$\mathrm{n}=\mathbf{7 7}$

\begin{tabular}{|c|c|c|c|}
\hline S.NO & Demographic Variables & Frequency (f) & Percentage $(\%)$ \\
\hline \multirow[t]{3}{*}{1} & Age (in years) & & \\
\hline & $18-36$ & 69 & 90 \\
\hline & $37-54$ & 8 & 10 \\
\hline \multirow[t]{3}{*}{2} & Gender & & \\
\hline & Male & 75 & 97 \\
\hline & Female & 2 & 3 \\
\hline \multirow[t]{5}{*}{3} & Educational Qualification & & \\
\hline & $5-10$ & 31 & 40 \\
\hline & Senior secondary & 30 & 39 \\
\hline & Graduation & 12 & 16 \\
\hline & Post -Graduation & 4 & 5 \\
\hline \multirow[t]{5}{*}{4} & Additional Qualification & & \\
\hline & Hotel Management & 10 & 13 \\
\hline & Master in Hotel Management & 1 & 1 \\
\hline & Bachelor in Physical Education & 1 & 1 \\
\hline & No Additional Qualification & 65 & 84 \\
\hline \multirow[t]{4}{*}{5} & Working Experience & & \\
\hline & $0-10$ years & 65 & 84 \\
\hline & 11-20 years & 11 & 14 \\
\hline & 21-30 years & 1 & 1 \\
\hline \multirow[t]{3}{*}{6} & $\begin{array}{l}\text { Previous Knowledge about food } \\
\text { hygiene }\end{array}$ & & \\
\hline & Yes & 76 & 99 \\
\hline & No & 1 & 1 \\
\hline
\end{tabular}

Table no.1Depictsthat majority69(90\%) of the study participants were between the age group of 18-16 years, the rest $8(10 \%)$ of the participants were between the age group of 37-54years.Most $75(97 \%)$ study participants were male.The educational status of the participants showed 31(40\%)had secondary level of education, 30(39\%) passed senior secondary level and 12(16\%) were graduate.Majority of the study participants 65(84\%) had no additional qualification,10(13\%) had done Hotel Management,1(1.29\%) had done Masters in Hotel Management,1(1.29\%) had done Bachelor in physical education.The majority 65(84\%) participants had working experience between 0-10 years,a few11(14\%) has working experience between 11-20 years, the rest $1(1 \%)$ has working experience between $21-30$ years.Almost all of the study participants $76(99 \%)$ had previous knowledge or exposure related to food hygiene

Graph No. 1 Level of knowledge about food hygiene among food handlers Arbitory scoring of level of knowledge of food handlers regarding Food hygiene with their gained scores

$$
\mathrm{n}=77
$$




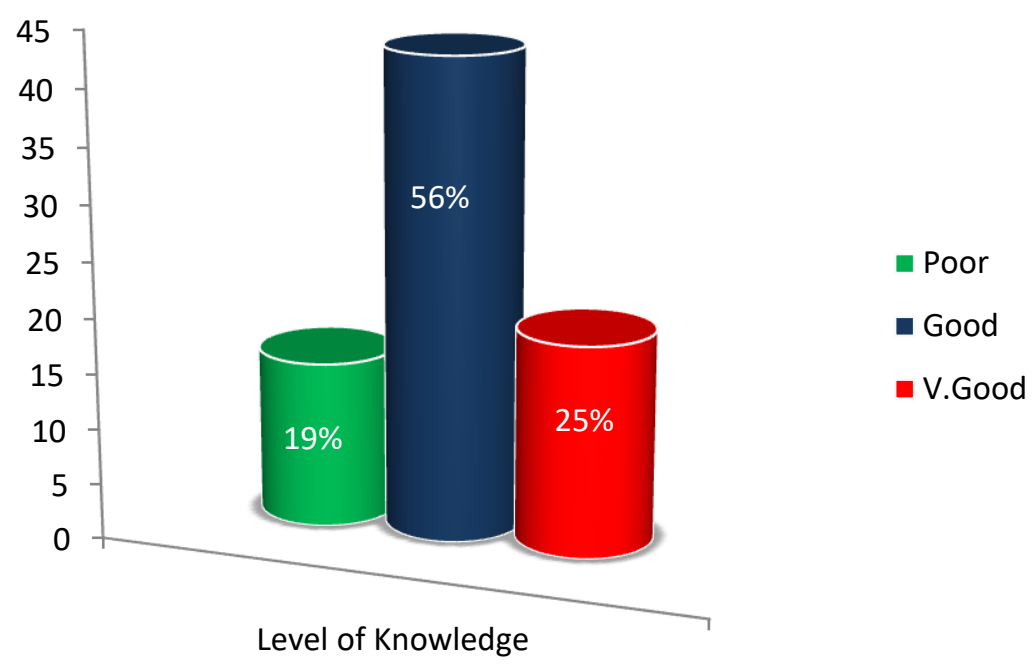

GraphNo. 1shows level of knowledge regarding food hygiene which is good among 43(56\%) the study participants, 19(25\%) had very good knowledge and only $15(19 \%)$ had poor knowledge.

Table No.2:-Item analysis of knowledge Questionnaire Percentage distribution of correct responses from study participants

\begin{tabular}{|c|l|c|c|}
\hline \multicolumn{2}{|c|}{ STATEMENTS } & YES (\%) & NO(\%) \\
& & \multicolumn{1}{|c|}{} & \\
\hline 1. & Improperly stored food is unhealthy & $\mathbf{9 9}$ & 1 \\
\hline 2. & $\begin{array}{l}\text { Right temperature of fridge can decreases the risk of food being } \\
\text { wasted }\end{array}$ & $\mathbf{8 8}$ & 12 \\
\hline 3. & $\begin{array}{l}\text { Wearing cap and gloves can increases the risk of food being } \\
\text { infected }\end{array}$ & 65 & 35 \\
\hline 4. & While serving food to the customer, gloves should be used & $\mathbf{9 1}$ & 9 \\
\hline 5. & Wash hands before making or serving food & $\mathbf{9 7}$ & 3 \\
\hline 6. & Overheating, increases food nutrition. & 75 & 25 \\
\hline 7. & Use cabbage after washing it off with salt and water & 61 & 39 \\
\hline 8. & Ajinomoto is harmful for health & 74 & 26 \\
\hline 9. & Utensils should be washed with surf water and scrubber & $\mathbf{9 5}$ & 5 \\
\hline 10. & Raw and uncooked food causes stomach related diseases & $\mathbf{9 2}$ & 8 \\
\hline 11. & With open wounded hand and wearing gloves on it food can be & 73 & 27 \\
\hline 12. & Served food gets contaminated and infected when flies sits on it & $\mathbf{8 8}$ & 12 \\
\hline 13. & $\begin{array}{l}\text { Extra oil of fried food should be removed by keeping it in } \\
\text { newspaper }\end{array}$ & 30 & 70 \\
\hline 14. & Kitchen cleaning should be done in every 15 days & 39 & 61 \\
\hline 15. & $\begin{array}{l}\text { The food that is more prone to mould must be used as soon as } \\
\text { possible }\end{array}$ & $\mathbf{8 3}$ & 17 \\
\hline 16. & Leftover food can be heated up to maximum of 5 times & 68 & 32 \\
\hline 17. & Mobile should not be used while cooking & 61 & 39 \\
\hline 18. & $\begin{array}{l}\text { While cooking or serving food, use hands to cover mouth while } \\
\text { sneezing }\end{array}$ & 39 & 61 \\
\hline 20. & Used oil can be used once again & $\mathbf{9 7}$ & 68 \\
\hline Store room should be cleaned periodically & 32 \\
\hline
\end{tabular}

Table No.2depicts the percentage level of yes and no responses to above given statements

Almost all the study participants $99 \%$ had the knowledge about causing health related problem if food is not stored properly. Majority $88 \%$ of the study participants had the knowledge about knowing right temperature of fridge can decrease the risk of food being wasted.Most $65 \%$ of the study participants had no knowledge about,wearing cap and gloves increases the risk of food infection. Majority $91 \%$ of the study participants knew that while serving food to the customer,gloves should be used.Majority $97 \%$ of the study participants knew proper hand washing before serving the food.Most $75 \%$ had no knowledge about nutrition loss with overheating. Most $61 \%$ of the study participants knew cabbage should be used after washing it off with salt water. 
Most $74 \%$ of the study participants had the knowledge about harmful effect of Ajinomoto.Majority $95 \%$ of the study participants knew that utensils must be washed thoroughly with surf water and soap.Majority $92 \%$ of the study participants had knowledge about raw and uncooked food can cause stomach related problems.Most $73 \%$ of the study participants had no knowledge about food can be prepared with an open wounded hand and wearing gloves on it. Majority $88 \%$ of study participants had the knowledge about served food, which gets contaminated and infected if flies would sit on it. Most $70 \%$ of the study participants had the knowledge about extra oil of fried food should be removed with newspaper.Most $61 \%$ of the participants had the knowledge about kitchen cleaning should be done in every 15 days.Majority $83 \%$ of the study participants had the knowledge about the food that are more prone to mold,must be used as soon as possible.Most $68 \%$ of the study participants had no knowledge about leftover food can be reheated up to maximum of 5 times. Most $61 \%$ of the study participants had the knowledge about mobile should not be used while cooking food.Most $61 \%$ of the study participants had the knowledge about at the time of cooking and serving food,if we sneeze, we should use our hands.Most $68 \%$ of the study participants had the knowledge about used oil can be used once again. Majority $97 \%$ of the study participants had the knowledge about store should be cleaned periodically.

Table No.3:-Association between knowledge and selected demographic variables of food handlers

$$
\mathbf{n}=\mathbf{7 7}
$$

\begin{tabular}{|c|c|c|c|c|}
\hline Socio dem & c variables & $\begin{array}{c}\text { At and } \\
\text { abovemedian(14) }\end{array}$ & $\begin{array}{c}\text { Below } \\
\text { median(14) }\end{array}$ & $\gamma$ VALVE \\
\hline 1.Age & $\begin{array}{l}18-36 \\
37-54\end{array}$ & $\begin{array}{l}45 \\
05\end{array}$ & $\begin{array}{l}23 \\
04\end{array}$ & 0.065 \\
\hline 2.Gender & $\begin{array}{l}\text { Male } \\
\text { Female }\end{array}$ & $\begin{array}{l}49 \\
01\end{array}$ & $\begin{array}{l}26 \\
01\end{array}$ & 1 \\
\hline 3.Qualifica & $\begin{array}{l}\text { Upto } 12 \\
\text { Above } 12\end{array}$ & $\begin{array}{l}30 \\
20\end{array}$ & $\begin{array}{l}25 \\
02\end{array}$ & 7.59* \\
\hline 4.Work Ex & $\begin{array}{l}0-15 \\
16-30\end{array}$ & $\begin{array}{l}47 \\
03\end{array}$ & $\begin{array}{l}25 \\
02\end{array}$ & 0.057 \\
\hline
\end{tabular}

Table No. 3 depicts the association between knowledge and selected demographic variables of food handlers.It shows that educational qualification of food handlers had statistical significant association with the level of knowledge.Other demographic variables like age,gender and working experience found to have no significant association with level of knowledge.

\section{Demographic profile}

Demographical data shows that 69 (90\%) of participants were between the age group of 18-36 years, and most of them were males 75 (97\%). The study results are also supported byMudeyAbhayBhausaheb, KesharwaniNaveeta, MudeyGargiAbhay, Goyal Ramchandra C, Dawale Ajay Kand. In the category of working experience $65(84 \%)$ participants were between 0-10 years. Most of the participants 76 (99\%) had previous knowledge about food hygiene. The study results were also supported by Diana Mary Varghese, Dr.Anice George, *Mrs. Malathi.G.Nayak. The study results show that 65 (84\%) participants were not having any additional qualification. The study also indicated by Lee Hai yen, Chick Wan nadirah wan, Beker Fatimah Abu, SaariNazamid and MahyudimorAiny.

\section{Knowledge score of food handlers regarding food hygiene}

The study shows that $19(25 \%)$ food handlers had very good level of knowledge regarding food hygiene, $43(56 \%)$ of the study participants had good level of knowledge and $15(19 \%)$ participants had poor knowledge regarding food hygiene. The study is also supported by Ackah.M.,Gyamfil E.T, Animl A.K, OseilJ,Hansen J.K, Agyemang O. The study results contradicted byMudeyAbhayBhausaheb, KesharwaniNaveeta, MudeyGargiAbhay, Goyal Ramchandra C, Dawale Ajay Kand and Wagh Vasant V.

\section{Other findings of the study}

- Most of the participants had wrong perception that heating food repeatly increases nutrition value of food.

- During the data collection most of the participants had an idea that the leftover food can be heated up to 5 times. 
- Participants during data collection knew that mobile phones should not be used while cooking.

\section{IV.Conclusion}

The study concluded that majority of participants were young, males and literate. Most of them were not having any additional qualification but they had previous knowledge regarding food hygiene. Majority of the participants had good level of knowledge regarding food hygiene. The study shows that educational qualification of food handlers had statistical association with the level of knowledge.

\section{Implication}

The findings of the study had been implicated for food hygiene practices in restaurants among food handlers. We can do extensive research in this area and research can be helpful in making mass awareness regarding food hygiene practices.

\section{Limitations}

The study was conducted on food handlers in selected restaurants of Doiwala.

Practices were not observed.

\section{Recommendations}

1. The same study can also be conducted on larger sample.

2. A training programme on food safety can be conducted for the food handlers in the restaurants to increase the effectiveness of the interventions.

3. The study recommends replicating the same study on a larger sample with probability sampling method which may help to draw conclusions that can be generalized.

\section{References}

[1]. WHOfoodhygiene [cited on 03-o2-2016] Available at, http://www.WHO.int/foodsafety areas-work/food-hygiene/en/

[2]. Chigozine O I.feadlike/O Kechu C Ironkaire/Prosper O.U. Adoga and chinomnso C Nnebue.Assessment of food handlers.2014(cited on 27feb 2016);Page no.10-15;Available at, http://www.tjmjurna

[3]. Chauhan neha, uniyalveena and RawatDevendraSingh,microbial profiling of street foods of different locations at dehradun city, India.(2015)[Cited on 27 May, 2016] Available at, http://www.ijcmas.com

[4]. Kaur Pinky, Rai Nishant. Bacteriological analysis of fresh vegetables from main market of Dehradun(2015)[cited on 27 may, 2016] Available at, http://www.google.co.in/search?ie=ISO-8859-

[5]. $1 \& \mathrm{Q}=$ bacteriological+analysis+of+fresh+vegetables+from+main+market+of+dehradun\&btnG=Search

[6]. 1AbhayBhausahebMudey,NaveetaKesharwani,GargiAbhayMudey,Ramchandra C. Goyal,Ajay K. Dawale,VasantV.Wagh.Health status and personal hygiene among food handlers working at food establishment around a Rural Teaching Hospital in Wardha district of Maharashtra,India(October 2010)[cited on 27 May, 2016] Available at,

[7]. www.ccsenet.org/journal/index.php/gjhs/article/viewFile/5723/5902.

[8]. K.K.Pandita, Farooq Jan, K.Rehana, MA Wani, Hina. A study of impact of education on Awareness, personal hygiene \& practices of food handlers of a Tertiary care Hospital in Kshmir, India(2013)[cited on 28 May 2016]. Available at, www.gjmedph.org/.../05vo2no2

[9]. Ms. Diana maryVargeshese, Dr.Anice George, Mrs.malathiG.nayak.conducted a descriptive survey 2013 in Udupi district restaurants regarding effectiveness of an information booklet on knowledge and practice on food safety among food handler()[cited on 28 May 2016]. Available at,

[10]. http://www.google.co.in/search?q=Ms.Diana+Mary+vageshese+Dr+anice+George+2013+in+udupi+district+restaurants+regarding

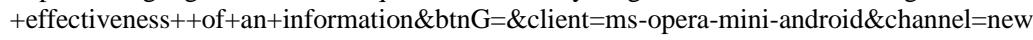

